\title{
The impact of social class and status on citizenship information need: the results of two national surveys of the population of the United Kingdom
}

\section{Rita Marcella and Graeme Baxter}

\begin{abstract}
This paper reports the key results of the Citizenship Information research project funded by the British Library Research and Innovation Centre. This research comprised two large scale surveys of the citizenship information needs of the UK public. The paper focuses upon the detailed analysis and examination of the results as they related to issues of social class and status. The research revealed that social class and status had an impact upon information need and information seeking behaviour, although the pattern emerging was not a simple one. Certain social classes and status groups were not exploiting public library information resources as effectively as they might; equally, certain groups were less willing (or able) to take advantage of new technologies to access information and participate in democratic activities. Those groups most willing to use a range of information sources were more conscious of disadvantage resulting from a lack of information. The paper concludes that there is a real danger of exclusion for certain groups of the UK population and that information policy must reflect an awareness of the most appropriate patterns of information dissemination in order to overcome barriers to access for each of these.
\end{abstract}

\section{Introduction and background}

Social exclusion is currently high on the UK political agenda. In December 1997 the Government established its Social Exclusion Unit with the remit to help improve Government action to reduce social exclusion by producing 'joined up solutions to joined up problems'[1]. At the same time the information profession and the academic community have paid considerable attention to the role that access to information can play in aiding democratic participation and helping to overcome social exclusion, as well as the implications for libraries and other information providers in facilitating information access.

This paper reports the key results of one such study: the British Library funded Citizenship Information research project [2], which aimed to investigate the citizenship information 
needs of the UK public and their preferred routes to the acquisition of such information. Citizenship information, as defined by the authors, is:

\begin{abstract}
information produced by or about national and local government, government departments and public sector organisations which may be of value to the citizen either as part of everyday life or in the participation by the citizen in government and policy formulation.
\end{abstract}

This research builds upon and complements other recent research projects and literature which have examined the role of information and information providers in assisting public participation and inclusion. For example, Leeds Metropolitan University conducted a British Library funded project which aimed to identify ways in which public libraries might contribute to a socially inclusive information society [3]; while the COOL project at the University of Wales Aberystwyth examined the benefits and problems of utilising the 'wired' public library for programmes which address social exclusion via Information and Communication Technologies (ICTs) [4]. Moore and Baigent [5] outlined how the EARL (Electronic Access to Resources in Libraries) Consortium might contribute to social inclusion; Matarasso [6], McKrell, Green and Harris [7] and Kerslake and Kinnell [8] reviewed and examined the social impact and effectiveness of public library community development initiatives; while Harris [9] investigated the type of framework necessary to help libraries work with local communities in developing indicators of their social benefit. Using a social audit approach, Linley and Usherwood [10] evaluated the social impact of public library services in Newcastle and Somerset; while Usherwood [11] also argued that the Career Development Group of the Library Association should recognize the value and social significance of its members' skills - skills which could be used to facilitate equality of access and social inclusion.

Some authors have examined the particular impact of social class on access to information. For example, the National Working Party on Social Inclusion [12], when considering potential locations for Community Resource Centres, discounted the use of public libraries, at least under their present culture, as they are significantly under-used by the lower socioeconomic groups who can view them as irrelevant, unappealing and having an 'institutional' atmosphere. In a number of articles [13,14,15] Pateman discussed the relationship between public libraries and social class, in particular the existing class bias in the provision and takeup of library services. In the most recent of these [15] he identified ongoing research into public libraries, including the Citizenship Information project which, he claimed, was failing 
to look at the issue of social class. It should be pointed out, however, that this project did indeed examine the impact of social class, and other demographic factors, on citizenship information need. With this in mind, the current article will focus upon the detailed analysis and examination of the key results in so far as they relate to issues of social class and status: broader discussions of results have been published in two earlier papers [16,17]. The authors are presently undertaking further analysis to explore the impact on information need of other variables tested, such as gender, age, ethnicity, disability, etc.

\section{Methodology}

The main data collection tools employed in the course of the project were two large-scale, nation-wide surveys. The first of these was a survey by questionnaire of 1,294 users of public libraries, Citizens Advice Bureaux $(\mathrm{CABx})$ and other generalist information and advice agencies throughout all 13 official UK regions. Systematic sampling was used, whereby staff at 42 service points in 27 different organisations handed a questionnaire to every 10th user (every 2nd user in the CABx and other advice agencies). This survey took place between June and October 1997. The second survey was a survey by personal doorstep interview, using the random walk sample method, of 898 adults residing in the same towns and cities in which the first survey had taken place. Each interviewer was provided with socio-economic and population data for their allocated town/city taken from the 1991 UK Census Small Area Statistics [18] and asked to conduct interviews in five local government electoral wards: the ward containing the highest percentage of residents belonging to Standard Occupational Classes IV and V (partly skilled and unskilled occupations), the ward with the lowest percentage of Classes IV and V, and three other wards spread across the cumulative population figures for that town/city. This survey took place between May and November 1998. The results of both surveys were analysed using SPSS for Windows, and significant statistical relationships between variables (at the 95\% confidence level) were identified using the chi-square test. The current paper will, of course, focus on the status and social class variables, and throughout the discussion that follows significant differences will be described in terms of \pm percentage points.

Table 1 illustrates the status of all 2,192 respondents. Of the Survey 1 respondents, 55.5\% were economically active (i.e. in work or looking for work), compared with the national figure of $48.9 \%$ [19]. Interestingly, the proportion of jobseekers in the CABx (22.5\%) and the other advice agencies (21.2\%) was effectively twice that in the public libraries (10.9\%). 
In Survey 2, just $42.8 \%$ of respondents were economically active. In particular, the doorstep interview methodology reached a greater proportion of the retired and those running a home as well as arguably those less aware of the value of 'information' as they had not proactively made the decision to visit an agency. Given that these are groups that may be deemed to face particularly significant barriers in the access to information, then the results are highly relevant: they also complement those of the first survey where a more dynamic and potentially 'informed' group of respondents was achieved.

\begin{tabular}{|l|r|r|r|r|r|r|}
\hline \multicolumn{2}{|c|}{ Table 1: Status of respondents } \\
\hline & \multicolumn{2}{|c|}{ Survey 1 } & \multicolumn{2}{c|}{ Survey 2} & \multicolumn{2}{c|}{ Totals } \\
\hline & No. & $\boldsymbol{\%}$ & No. & \% & No. & \% \\
\hline In paid employment & 446 & 34.5 & 259 & 28.8 & 705 & 32.2 \\
\hline Self employed & 95 & 7.3 & 61 & 6.8 & 156 & 7.1 \\
\hline Seeking work & 177 & 13.7 & 65 & 7.2 & 242 & 11.0 \\
\hline Retired & 269 & 20.8 & 307 & 34.2 & 576 & 26.3 \\
\hline Running a home & 86 & 6.6 & 119 & 13.3 & 205 & 9.4 \\
\hline Student & 182 & 14.1 & 78 & 8.7 & 260 & 11.9 \\
\hline Status not specified & 39 & 3.0 & 9 & 1.0 & 48 & 2.2 \\
\hline Totals & $\mathbf{1 2 9 4}$ & $\mathbf{1 0 0}$ & $\mathbf{8 9 8}$ & $\mathbf{1 0 0}$ & $\mathbf{2 1 9 2}$ & $\mathbf{1 0 0}$ \\
\hline
\end{tabular}

In both surveys, employed respondents were asked to specify their occupation, and those who did were allocated a social class using the Standard Occupational Classification [20]. These are detailed in Table 2. Compared with national figures, the respondents came to a greater extent proportionally from the professional and managerial categories $(50.0 \%$ of the employed respondents belonged to Classes I and II, compared with $35.6 \%$ of the UK population); while the proportion of the samples with a skilled, manual occupation (8.3\%) was far fewer than that for the UK as a whole (20.6\%) [19]. Proportions of the other social classes were close to national figures, therefore it is believed that the sample is representative enough of the UK population as a whole for generalisations to be drawn. In Survey 1, the proportion of Class I and II respondents in the public libraries (51.7\%) was significantly higher than in the $\operatorname{CABx}(38.1 \%)$ and other agencies $(33.3 \%)$ : coupled with the low proportion of jobseekers already mentioned, this might suggest that public libraries are serving the groups least in danger of social exclusion.

\begin{tabular}{|c|c|c|c|c|c|c|c|}
\hline \multirow{2}{*}{\multicolumn{2}{|c|}{ Social Class }} & \multicolumn{2}{|c|}{ Survey 1} & \multicolumn{2}{|c|}{ Survey 2} & \multicolumn{2}{|c|}{ Totals } \\
\hline & & No. & $\%$ & No. & $\%$ & No. & $\%$ \\
\hline I & Professional, etc. occupations & 39 & 9.5 & 49 & 17.0 & 88 & 12.6 \\
\hline II & Managerial \& Technical & 159 & 38.9 & 102 & 35.4 & 261 & 37.4 \\
\hline
\end{tabular}




\begin{tabular}{|l|r|r|r|r|r|r|}
\hline occupations & & & & & & \\
\hline III(N) Skilled occupations non-manual & 114 & 27.9 & 55 & 19.1 & 169 & 24.2 \\
\hline III(M) Skilled occupations manual & 41 & 10.0 & 17 & 5.9 & 58 & 8.3 \\
\hline IV Partly skilled occupations & 42 & 10.3 & 48 & 16.7 & 90 & 12.9 \\
\hline V Unskilled occupations & 14 & 3.4 & 17 & 5.9 & 31 & 4.4 \\
\hline Totals & $\mathbf{4 0 9}$ & $\mathbf{1 0 0}$ & $\mathbf{2 8 8}$ & $\mathbf{1 0 0}$ & $\mathbf{6 9 7}$ & $\mathbf{1 0 0}$ \\
\hline
\end{tabular}

\section{Survey 1: results of the questionnaire}

Survey 1 began with an open question which asked respondents to give an example of an occasion on which they had been required to look for information to help them make a decision, solve a problem or understand something a little better. In total, 769 (59.4\%) respondents cited such an instance, with examples relating to education (25.6\%), leisure (16.9\%), health care (11.6\%), welfare benefits (10.7\%), legal issues (9.8\%) and employment $(8.3 \%)$ being the most prominent. When compared with figures for the sample as a whole, examples relating to education were cited more frequently by students $(+43.9$ percentage points) and, perhaps more surprisingly, Class IV (partly skilled) respondents $(+15.6)$; while leisure examples were mentioned more by the retired $(+22.2)$. Health care was cited more by Class IV respondents $(+11.9)$; legal issues were mentioned more frequently by the employed (+18.2); and employment, unsurprisingly, was cited most by jobseekers $(+13.6)$.

Respondents were asked where they had gone to obtain the information and for the great majority $(66.7 \%)$ the public library had been their resource, with $\mathrm{CABx}(17.7 \%)$ forming the only other significant source. While the public library was the favourite source for all status groups and all classes, CABx were a particularly important source for Class III(M) respondents (skilled manual occupations) (+20.4 points when compared with the entire sample), jobseekers (+12.7) and those running a home (+9.0).

The 769 respondents who had looked for information in the past were asked if they had had any difficulties in obtaining the information, and overall 196 (25.5\%) had encountered problems. Jobseekers $(+8.1$ points) and students $(+6.4)$ cited problems more frequently than the other groups. A similar question was asked of the sample as a whole, and 308 respondents $(23.8 \%)$ had been in the past unable to access information which they needed in order to make a decision or solve a problem. Again, jobseekers $(+8.7)$ had encountered proportionately greater difficulties than other groups. 
The entire survey sample was presented with a list of 23 subjects and asked to indicate which they had wanted to find out more about in the past, and which they felt they might want to find out more about in the future. Table 3 illustrates the response. As can be seen, the top six subjects required in the past (leisure, education, employment, transport and travel, legal issues and health care) were still regarded as the six types of information most likely to be required in the future, although in a slightly different order of preference. Less interest was anticipated in employment (-1.2 points), transport (-2.6), leisure (-3.1) and most significantly education (-8.8). There was a significantly increased perception of information need in relation to the European Union in the future.

\begin{tabular}{|l|c|c|c|c|c|c|}
\hline \multicolumn{7}{|l|}{ Table 3: Past and predicted information need } \\
\hline & \multicolumn{2}{|c|}{ Past need } & \multicolumn{2}{|c|}{ Future need } & \multicolumn{2}{c|}{ Net difference } \\
\hline Subject & $\%$ & Pos. & $\%$ & Pos. & \pm pts & \pm Pos. \\
\hline Leisure & 38.8 & 1 & 35.7 & 1 & -3.1 & same \\
\hline Education & 36.9 & 2 & 28.1 & 5 & -8.8 & -3 \\
\hline Employment & 33.5 & 3 & 32.3 & 2 & -1.2 & +1 \\
\hline Transport/travel & 31.6 & 4 & 29.0 & 4 & -2.6 & same \\
\hline Legal & 25.2 & 5 & 29.8 & 3 & +4.6 & +2 \\
\hline Health care & 23.6 & 6 & 25.8 & 6 & +2.2 & same \\
\hline Welfare benefits & 21.9 & 7 & 20.1 & 14 & -1.8 & -7 \\
\hline Local council & 21.6 & 8 & 23.8 & 7 & +2.2 & +1 \\
\hline Financial & 21.1 & 9 & 23.5 & 9 & +2.4 & same \\
\hline Environmental & 20.3 & 10 & 21.6 & 11 & +1.3 & -1 \\
\hline Politics/Govt. & 20.1 & 11 & 21.0 & 12 & +0.9 & -1 \\
\hline Taxation & 19.6 & 12 & 23.6 & 8 & +4.0 & +4 \\
\hline Housing & 19.5 & 13 & 19.2 & 17 & -0.3 & -4 \\
\hline Family/Personal & 17.9 & 14 & 19.5 & 16 & +1.6 & +2 \\
\hline Tech. \& comms. & 17.2 & 15 & 19.6 & 15 & +2.4 & same \\
\hline Health \& Safety & 16.8 & 16 & 16.8 & 19 & 0 & -3 \\
\hline Citizens' rights & 15.6 & 17 & 20.6 & 13 & +5.0 & +4 \\
\hline European Union & 13.6 & 18 & 21.9 & 10 & +8.3 & +8 \\
\hline Equal rights & 11.9 & 19 & 13.8 & 21 & +1.9 & -2 \\
\hline Business opports. & 11.7 & 20 & 17.6 & 18 & +5.9 & +2 \\
\hline Crime/security & 11.1 & 21 & 14.6 & 20 & +3.5 & +1 \\
\hline Consumer/credit & 10.7 & 22 & 13.3 & 22 & +2.6 & same \\
\hline Immigration & 6.9 & 23 & 8.7 & 23 & +1.8 & same \\
\hline
\end{tabular}

With regard to status and past need, employed respondents displayed a significantly greater need for information on employment, consumer and legal issues; while jobseekers had had a greater need for employment and welfare benefits information, but less need for leisure information. Students had been more interested in information on immigration and the environment, but were less interested in local council information, taxation, and financial and legal issues. Those respondents who were running a home displayed a greater need for benefits and family/personal information, but less need for EU, health and safety, business 
and equal rights information. The retired respondents, meanwhile, indicated a significantly lesser past need for information on education, health and safety, employment, housing, family, business, legal issues, equal rights, technology and leisure. For future needs, findings were similar, although jobseekers predicted a significantly greater need for information on housing, taxation, business opportunities and citizens' rights; while students forecast a greater need for 13 of the 23 subjects, including employment, housing, taxation, welfare benefits, business opportunities and consumer issues. Those respondents running a home perceived a greater future need for health care information.

With regard to social class and past need, there had been a significantly greater need among the higher classes (i.e. professional, managerial and skilled occupations) than the lower classes (partly skilled and unskilled occupations) for information on national politics, local government, the EU, legal issues, technology and communications, and the environment. For future needs, however, a similar gap between the classes was only statistically significant with EU and leisure information.

Respondents were asked to indicate (from a list of 13 reasons) the reasons why they had wanted citizenship information in the past, and to predict why they might want such information in the future. Table 4 illustrates the response. Almost half of the survey sample indicated past educational and study reasons, and significant numbers also cited work-related reasons, family and personal reasons, and a simple general interest. These remained the four most likely reasons for requiring information in the future, although there was a significant reduction in predicted educational reasons (-12.4). 


\begin{tabular}{|l|c|c|c|c|c|c|}
\hline \multicolumn{7}{|l|}{ Table 4: Past and predicted reasons for requiring information } \\
\hline & \multicolumn{2}{|c|}{ Past reasons } & Future reasons & \multicolumn{2}{c|}{ Net Difference } \\
\hline Reasons & $\%$ & Pos. & $\%$ & Pos. & $\pm \%$ & \pm Pos. \\
\hline Educational/study & 48.8 & 1 & 36.4 & 1 & -12.4 & same \\
\hline Work-related & 35.2 & 2 & 32.6 & 3 & -2.6 & -1 \\
\hline General interest & 33.3 & 3 & 32.7 & 2 & -0.6 & +1 \\
\hline Family/personal & 32.9 & 4 & 28.8 & 4 & -4.1 & same \\
\hline Recreational & 28.2 & 5 & 25.4 & 6 & -2.8 & -1 \\
\hline Job-seeking & 27.7 & 6 & 26.9 & 5 & -0.8 & +1 \\
\hline Health & 23.4 & 7 & 21.8 & 8 & -1.6 & -1 \\
\hline Financial & 22.2 & 8 & 25.0 & 7 & +2.8 & +1 \\
\hline Legal & 19.4 & 9 & 20.0 & 9 & +0.6 & same \\
\hline Business/commercial & 12.1 & 10 & 13.1 & 10 & +1.0 & same \\
\hline $\begin{array}{l}\text { Work with a representative } \\
\text { /interest group }\end{array}$ & 10.9 & 11 & 11.1 & 11 & +0.2 & same \\
\hline Political decision-making & 7.7 & 12 & 8.7 & 12 & +1.0 & same \\
\hline Religious & 6.6 & 13 & 6.3 & 13 & -0.3 & same \\
\hline
\end{tabular}

In terms of status and past reasons for requiring information, employed respondents had had a greater need for work-related and business reasons; while jobseekers unsurprisingly emphasised jobseeking reasons but had a lesser requirement for recreational information. Family and health reasons were cited as the most important by those respondents running a home; while retired respondents displayed less of a need for educational, work-related, jobseeking, business and legal reasons. Students, meanwhile, indicated a greater past tendency to require information for educational, political and religious reasons, but less need for family, health, financial and legal reasons. With regard to future reasons, findings were similar although jobseekers optimistically cited a greater future need for information for work-related, business and financial reasons.

In terms of social class, for both the past and predicted future, the higher classes (particularly I and II, the professional and managerial occupations) cited educational, work-related, business and recreational reasons more frequently than the lower classes.

Survey 1 respondents were given a list of organisations and people and asked to indicate whether they would approach them for information. The response is shown in Table 5. Over three quarters of respondents would use public libraries, while between half and three quarters would approach $\mathrm{CABx}$, post offices, government departments and agencies, or their family and friends. 


\begin{tabular}{|c|c|c|c|c|c|c|c|c|c|c|c|c|}
\hline \multirow{2}{*}{$\begin{array}{l}\text { Organisations/ } \\
\text { People }\end{array}$} & \multicolumn{5}{|c|}{ Status } & \multicolumn{6}{|c|}{ Social class } & \multirow[b]{2}{*}{$\begin{array}{c}\text { Entire } \\
\text { Sample }\end{array}$} \\
\hline & Empl & $\begin{array}{l}\text { Seek } \\
\text { work }\end{array}$ & Retd & $\begin{array}{c}\text { Run } \\
\text { home }\end{array}$ & Studt & I & II & $\begin{array}{l}\text { III } \\
\text { (N) }\end{array}$ & $\begin{array}{l}\text { III } \\
\text { (M) }\end{array}$ & IV & $\mathbf{V}$ & \\
\hline Public libraries & 80.6 & 71.2 & 69.9 & 76.7 & 89.6 & 97.4 & 85.5 & 77.2 & 68.3 & 78.6 & 57.1 & 77.3 \\
\hline Family/friends & 65.2 & 63.8 & 42.4 & 61.6 & 79.1 & 66.7 & 69.2 & 71.1 & 63.4 & 52.4 & 50.0 & 61.7 \\
\hline Govt. depts & 56.7 & 57.1 & 48.3 & 54.7 & 51.6 & 59.0 & 61.0 & 61.4 & 51.2 & 47.6 & 57.1 & 53.9 \\
\hline Post Offices & 55.1 & 52.5 & 46.1 & 53.5 & 59.9 & 56.4 & 56.6 & 57.9 & 48.8 & 57.1 & 57.1 & 53.1 \\
\hline$\overline{C A B x}$ & 53.0 & 58.2 & 40.1 & 50.0 & 45.1 & 35.9 & 54.1 & 54.4 & 70.7 & 54.8 & 57.1 & 50.3 \\
\hline Prof. people & 51.6 & 47.5 & 37.9 & 57.0 & 54.4 & 69.2 & 54.7 & 52.6 & 58.5 & 50.0 & 21.4 & 49.0 \\
\hline Local council & 45.7 & 42.9 & 39.4 & 50.0 & 35.2 & 48.7 & 49.1 & 44.7 & 41.5 & 38.1 & 42.9 & 42.5 \\
\hline Academic libs & 41.0 & 36.2 & 25.3 & 26.7 & 67.0 & 66.7 & 52.2 & 30.7 & 29.3 & 23.8 & $\overline{14.3}$ & 39.4 \\
\hline $\begin{array}{l}\text { Other advice } \\
\text { centres }\end{array}$ & 33.5 & 36.2 & 16.0 & 25.6 & 44.5 & 23.1 & 37.7 & 32.5 & 34.1 & 35.7 & 42.9 & 31.4 \\
\hline MPs & 25.1 & 31.1 & 21.2 & 27.9 & 28.6 & 23.1 & 28.9 & 24.6 & 19.5 & 26.2 & 21.4 & 25.6 \\
\hline $\begin{array}{l}\text { Prof./Trade } \\
\text { Associations }\end{array}$ & 29.9 & 22.0 & 12.3 & 9.3 & 24.2 & 64.1 & 42.1 & 18.4 & 26.8 & 19.0 & 7.1 & 22.6 \\
\hline $\begin{array}{l}\text { Chambers of } \\
\text { Commerce }\end{array}$ & 10.9 & 11.9 & 1.9 & 7.0 & 14.8 & 12.8 & 16.4 & 9.6 & 9.8 & 4.8 & 7.1 & 9.4 \\
\hline
\end{tabular}

The public library was the top response of all status groups and classes, although for Class V (unskilled) respondents it was on an equal footing with government departments, post offices and $\mathrm{CABx}$. When compared with the response for the sample as a whole, students would be more frequent users of academic libraries (+27.6 points), family and friends $(+17.4)$, other advice centres $(+13.1)$, public libraries $(+12.3)$ and post offices $(+6.8)$; jobseekers would approach $\mathrm{CABx}(+7.9)$ and MPs (+5.5) more frequently; while professional and trade associations would be more popular with employed respondents (+7.3). In general, all sources would be used less frequently by the retired and those running a home, although the latter group indicated a significant preference for approaching professional people $(+8.0)$. In terms of social class, public libraries, academic libraries and professional/trade associations would be approached most frequently by those in Classes I and II (professional/managerial occupations) and least frequently by those in Class V (unskilled occupations). So again there is evidence of the impact of social class on present patterns of use of information agencies.

From a list of methods of obtaining information, respondents were asked to indicate their favourite three methods. This is shown in Table 6. There were few significant differences amongst the status groups: obtaining information by face to face communication, using a computer and watching television were all cited most by students and least by the retired, which is not what one might have hypothesised. Highly significantly, social class had an impact upon use of a computer, which was cited most by the professional respondents $(36.1 \%)$ and least by those in unskilled occupations (nil). 


\begin{tabular}{|c|c|c|c|c|c|c|c|c|c|c|c|c|}
\hline \multirow[b]{2}{*}{ Method } & \multicolumn{5}{|c|}{ Status } & \multicolumn{6}{|c|}{ Social class } & \multirow[b]{2}{*}{$\begin{array}{l}\text { Entire } \\
\text { Sampl }\end{array}$} \\
\hline & Empl & $\begin{array}{l}\text { Seek } \\
\text { work }\end{array}$ & \begin{tabular}{|l|} 
Retd \\
\end{tabular} & $\begin{array}{l}\text { Run } \\
\text { home }\end{array}$ & Studt & I & II & $\begin{array}{l}\text { III } \\
\text { (N) }\end{array}$ & $\begin{array}{l}\text { III } \\
\text { (M) }\end{array}$ & IV & $\mathbf{V}$ & \\
\hline $\begin{array}{l}\text { Talking face to } \\
\text { face }\end{array}$ & 39.4 & 32.8 & 27.1 & 36.0 & 42.3 & 25.6 & 43.4 & 38.6 & 53.7 & 47.6 & 14.3 & \\
\hline Reading a book & 32.3 & 23.2 & \begin{tabular}{|l|l|}
30.9 \\
\end{tabular} & 27.9 & 30.2 & 48.7 & 33.3 & \begin{tabular}{|l|l|}
38.6 \\
\end{tabular} & 22.0 & 35.7 & 21.4 & 34.6 \\
\hline $\begin{array}{l}\text { Looking through } \\
\text { a collection }\end{array}$ & 32.0 & 31.1 & \begin{tabular}{|l|}
30.5 \\
\end{tabular} & 30.2 & 22.5 & 28.2 & 35.2 & \begin{tabular}{|l|}
30.7 \\
\end{tabular} & 39.0 & 28.6 & 42.9 & 34.2 \\
\hline $\begin{array}{l}\text { Reading a } \\
\text { newspaper }\end{array}$ & 23.5 & 29.9 & \begin{tabular}{|l|}
29.4 \\
\end{tabular} & 30.2 & 23.6 & 43.6 & 27.0 & \begin{tabular}{|l|l|}
22.8 \\
\end{tabular} & 9.8 & 21.4 & 28.6 & 31.0 \\
\hline $\begin{array}{l}\text { Talking by } \\
\text { telephone }\end{array}$ & 25.1 & 17.5 & 15.6 & 26.7 & 18.7 & 20.5 & 26.4 & 27.2 & 22.0 & 23.8 & 21.4 & 24.6 \\
\hline Watching TV & 17.2 & 22.6 & 13.8 & 11.6 & 24.2 & 25.6 & 12.6 & 19.3 & 22.0 & 16.7 & 42.9 & 20.3 \\
\hline $\begin{array}{l}\text { Listening to the } \\
\text { radio }\end{array}$ & 18.3 & 16.9 & \begin{tabular}{|l|l}
14.1 \\
\end{tabular} & 19.8 & 9.3 & 17.9 & 21.4 & \begin{tabular}{|l|l}
16.7 \\
\end{tabular} & 19.5 & 16.7 & 28.6 & 19.8 \\
\hline $\begin{array}{l}\text { Reading a } \\
\text { leaflet/pamphlet }\end{array}$ & 13.9 & 16.9 & \begin{tabular}{|l|}
11.5 \\
\end{tabular} & $\begin{array}{l}11.6 \\
\end{array}$ & 16.5 & 12.8 & 12.6 & 14.9 & $\begin{array}{l}14.6 \\
\end{array}$ & 21.4 & 14.3 & 15.8 \\
\hline $\begin{array}{l}\text { Using a } \\
\text { computer }\end{array}$ & 12.0 & 15.8 & 2.2 & 7.0 & 26.4 & 33.3 & 14.5 & 8.8 & 14.6 & 7.1 & Nil & 13.9 \\
\hline $\begin{array}{l}\text { Reading a } \\
\text { magazine }\end{array}$ & \begin{tabular}{ll|}
11.1 \\
\end{tabular} & 9.6 & 8.9 & 7.0 & 12.6 & 12.8 & 10.7 & 12.3 & 4.9 & 16.7 & 14.3 & 12.6 \\
\hline Writing a letter & 6.7 & 7.9 & 10.0 & 5.8 & 11.0 & 2.6 & 7.5 & 8.8 & 9.8 & 7.1 & Nil & 9.8 \\
\hline
\end{tabular}

Respondents were asked how often they would use computers to look for information, if public access to computers was made more widely available. From a short list of public places, identified as likely locations for public access computers in the government.direct Green Paper [21], they were asked which they would visit to use computers (see Table 7). Overall, 969 (74.9\%) of the respondents indicated that they would use computers on at least an occasional basis in at least one of the places listed. Unsurprisingly, proposed use of public access computers was significantly higher amongst students and lower amongst the retired. In terms of social class, use of computers in public libraries would be highest amongst Class II respondents (86.2\%) and lowest amongst those in Class IV (54.8\%).

\begin{tabular}{|c|c|c|c|c|c|c|c|c|c|c|c|c|}
\hline \multirow{2}{*}{$\begin{array}{l}\text { Location of } \\
\text { computers }\end{array}$} & \multicolumn{5}{|c|}{ Status } & \multicolumn{6}{|c|}{ Social class } & \multirow[b]{2}{*}{$\begin{array}{c}\text { Entire } \\
\text { Sample }\end{array}$} \\
\hline & Empl & $\begin{array}{c}\text { Seek } \\
\text { work }\end{array}$ & Retd & $\begin{array}{c}\text { Run } \\
\text { home }\end{array}$ & Studt & I & II & $\begin{array}{l}\text { III } \\
\text { (N) }\end{array}$ & $\begin{array}{l}\text { III } \\
\text { (M) }\end{array}$ & IV & $\mathbf{V}$ & \\
\hline Public library & 79.5 & 75.1 & 48.3 & 70.0 & 91.8 & 79.5 & 86.2 & 83.3 & 78.0 & 54.8 & 71.4 & 72.6 \\
\hline Post office & 42.1 & 48.6 & 14.1 & 36.0 & 52.2 & 43.6 & 47.2 & 42.1 & 41.5 & 26.2 & 64.3 & $\begin{array}{ll}37.8 \\
\end{array}$ \\
\hline Shopping centre & 39.2 & 41.2 & 10.8 & 29.1 & 57.7 & 41.0 & 40.9 & 42.1 & 43.9 & 23.8 & 57.1 & 35.1 \\
\hline Town hall & 33.1 & 37.3 & 8.2 & 27.9 & 44.5 & 33.3 & 35.2 & 33.3 & 34.1 & 19.0 & 50.0 & 29.2 \\
\hline
\end{tabular}


Finally in Survey 1, respondents were asked if they believed that access to accurate and unbiased information is important for exercising their rights as citizens. A highly significant majority (79.2\%) believed that information access is very important, while a further $15.1 \%$ believed it to be quite important; $1.5 \%$ did not know. Interestingly, student respondents appeared to feel less certain of the importance of information access: 69.2\% (-10.0) believed it to be very important, $22.5 \%(+7.4)$ felt it was quite important and $4.9 \%(+3.5)$ did not know.

\section{Survey 2: results of the personal doorstep interviews}

The second survey began with an open question which asked the respondents to identify what they believed to be the single most important issue in UK current affairs. A wide range of issues was cited, although the top responses were: the Northern Ireland situation; the state of the education system; health issues and the National Health Service; the EU and UK participation in European Monetary Union; the UK economy; and unemployment. Interest in the education system was significantly greater amongst students and those running a home; retired respondents and those running a home displayed a greater interest in health issues; self employed respondents were more interested in the economy; while unsurprisingly, employment issues were the prime concern of the jobseekers. There were no significant differences between the social classes.

Respondents were asked from which source they had obtained most of their information on their chosen current affairs issue. The media dominated overall for subjects, with at least one form (television, radio or newspapers) being cited by over $75 \%$ of respondents in each case. Use of television as the main information source was greater among Classes III, IV and V (skilled, partly skilled and unskilled occupations), while use of the press was greater among Classes I and II (professional and managerial).

The next part of the survey consisted of a more detailed investigation of three current issues chosen by the researchers as representative of citizenship information need at international, national and local levels: European Monetary Union, the BSE crisis and local government financial cutbacks (see Table 8). 


\begin{tabular}{|l|c|c|c|c|c|c|c|c|c|c|c|c|}
\hline \multicolumn{10}{|c|}{ Table 8: Three current issues - well informed respondents (\%) } \\
\hline \multirow{3}{*}{ Issue } & \multicolumn{10}{|c|}{ Status } \\
\cline { 2 - 15 } & Empl & $\begin{array}{c}\text { Seek } \\
\text { work }\end{array}$ & Retd & $\begin{array}{c}\text { Run } \\
\text { home }\end{array}$ & Studt & I & II & $\begin{array}{c}\text { III } \\
\text { (N) }\end{array}$ & $\begin{array}{c}\text { III } \\
\text { (M) }\end{array}$ & IV & V & $\begin{array}{c}\text { Entire } \\
\text { Sample }\end{array}$ \\
\hline Single currency & 22.2 & 24.6 & 32.6 & 19.3 & 11.5 & 40.8 & 22.5 & 16.4 & 11.8 & 16.7 & 11.8 & $\mathbf{2 4 . 6}$ \\
\hline BSE & 59.4 & 60.0 & 63.2 & 55.5 & 48.7 & 65.3 & 72.5 & 58.2 & 52.9 & 47.9 & 41.2 & $\mathbf{5 9 . 2}$ \\
\hline Council cuts & 30.6 & 27.7 & 42.7 & 38.7 & 23.1 & 40.8 & 26.5 & 29.1 & 11.8 & 31.3 & 29.4 & $\mathbf{3 5 . 0}$ \\
\hline
\end{tabular}

Just under $75 \%$ of respondents indicated that they would like to find out more about the Single Currency, with the mass media (38.7\%) and public libraries $(21.7 \%)$ being the most likely sources of information. Oddly, given the Survey 1 findings, potential use of public libraries was particularly high amongst jobseekers (33.3\%; i.e. +11.6). A significant proportion (21.6\%) of those running a home felt that there should be a government information programme relating to this issue. Again, television was cited more frequently by the lower classes while newspapers were favoured by the higher classes. The vast majority (80.4\%) of the overall sample felt that the government was not doing enough to inform the public about the Single Currency.

The majority of respondents (59.2\%) felt well informed about BSE, although Classes IV (47.9\%) and V (41.2\%) felt less well informed than Classes I (65.3\%) and II (72.5\%). The media (26.6\%) and public libraries (19.4\%) were again the most likely sources for those who felt poorly informed. A slight majority $(55.2 \%)$ felt that the government was not doing enough to inform the public about BSE. When asked how they might make their own feelings known to the government on this issue, the preferred methods were contacting a local MP (38.6\%) or a government minister or department $(10.0 \%)$, although over a third $(35.6 \%)$ were not interested in making their feelings known. There were no significant variations, in terms of class and status, in the response to this question.

Almost two-thirds (63.4\%) of respondents felt poorly informed about local government cutbacks, with local council offices (31.1\%), local newspapers (11.6\%) and public libraries (10.4\%) proving the most likely sources of additional information. The majority (71.6\%) believed that their local council was not doing enough to inform them about cutbacks, with the students in the sample being particularly critical of the level of communication (88.5\%). In making their own feelings known on this subject, significant proportions would contact local councillors (20.3\%), their local MP (19\%) and local council offices (17.5\%), although over a quarter (26.2\%) were again not interested in making their feelings known. 
Communicating with their local councillor was a particularly favoured option of the retired respondents $(42.1 \%)$.

The survey then focused on 'survival' information, i.e. information that might help individuals to overcome the problems that occur in day-to-day life. It asked if respondents had ever encountered a problem relating to employment, education, housing or welfare benefits, and elicited brief details on the nature of these problems and the information sources used to help solve the problems. Overall, 328 (36.5\%) of the respondents indicated that they had had a problem relating to one or more of the four issues (see Table 9). Just $19.2 \%$ of the retired respondents indicated a problem of any kind.

\begin{tabular}{|c|c|c|c|c|c|c|c|c|c|c|c|c|}
\hline \multicolumn{13}{|c|}{ Table 9: Type of problem encountered (\%) } \\
\hline \multirow{2}{*}{$\begin{array}{l}\text { Type of } \\
\text { problem }\end{array}$} & \multicolumn{5}{|c|}{ Status } & \multicolumn{6}{|c|}{ Social class } & \\
\hline & Empl & $\begin{array}{l}\text { Seek } \\
\text { work }\end{array}$ & Retd & $\begin{array}{c}\text { Run } \\
\text { home }\end{array}$ & Studt & I & II & $\begin{array}{l}\text { III } \\
\text { (N) }\end{array}$ & $\begin{array}{l}\text { III } \\
\text { (M) }\end{array}$ & IV & $\mathbf{V}$ & $\begin{array}{c}\text { Entire } \\
\text { Sample }\end{array}$ \\
\hline Employment & 22.8 & 26.2 & 4.9 & 12.6 & 23.1 & 30.6 & 24.5 & 18.2 & 17.6 & 27.1 & Nil & 15.7 \\
\hline Education & 17.5 & 15.4 & 2.3 & 17.6 & 29.5 & 16.3 & 18.6 & 14.5 & 5.9 & 20.8 & 17.6 & 13.1 \\
\hline Housing & 17.5 & 20.0 & 6.8 & 14.3 & 17.9 & 10.2 & 22.5 & 10.9 & 11.7 & 22.9 & $\overline{11.8}$ & 13.6 \\
\hline Welfare benefits & 15.3 & 24.6 & 10.7 & 19.3 & 15.4 & 8.2 & 18.6 & 9.1 & 11.8 & 22.9 & 11.8 & 15.0 \\
\hline $\begin{array}{l}\text { Total citing one } \\
\text { or more types }\end{array}$ & 45.6 & 50.8 & 19.2 & 41.2 & 47.4 & 42.9 & 50.0 & 34.5 & 35.3 & 58.3 & 29.4 & 36.5 \\
\hline
\end{tabular}

141 respondents (15.7\%) indicated an employment problem, including finding work and dealing with redundancy or unfair dismissal. Employment problems were cited most frequently by jobseekers $(26.2 \%)$ and least by retired respondents (4.9\%). Job centres and newspapers were the information sources used most frequently to help respondents solve these problems.

A smaller proportion (13.1\%) cited an education problem, such as selecting a school or university or obtaining funding or grants. Educational problems were identified most frequently by students $(29.5 \%)$ and least by the retired (2.3\%). Local education authorities, schools and universities and family and friends were the favoured information sources.

Housing problems were indicated by $13.6 \%$ of the respondents; these included obtaining council housing and dealing with problem neighbours. Jobseekers had encountered housing problems most frequently (20\%), with retired respondents again indicating fewer problems $(6.8 \%)$. While there were significant differences between the social classes, these followed no clear patterns: housing problems were cited most frequently by Classes IV (22.9\%) and II 
$(22.5 \%)$ and least by Classes $\operatorname{III}(\mathrm{N})(10.9 \%)$ and I (10.2\%). Most respondents had approached council housing departments and local councillors for help.

Exactly $15 \%$ of the sample had encountered a welfare benefits problem. All were related to claiming or establishing entitlement to a range of benefits. They were cited most frequently by Class IV respondents (22.9\%) and least by those in Class I (8.2\%). The main information sources cited were Department of Social Security (DSS) offices, CABx, council social services departments and family and friends.

The survey then explored the concept that exclusion from information creates disadvantage. Respondents were asked to give an example of an occasion when not being able to obtain information had proven a disadvantage and over a quarter (26.1\%) provided such an example (see Table 10). These related to a wide range of issues, including financial matters, health and medical issues and marital/relationship problems. Interestingly, such incidences were cited more frequently by those respondents that might not normally be associated with disadvantage, i.e. those in Classes I (42.9\%) and II (33.3\%). This might relate more to a lack of awareness of disadvantage amongst those in the lower social classes.

\begin{tabular}{|c|c|c|c|c|c|c|c|c|c|c|c|c|}
\hline \multicolumn{13}{|c|}{ Table 10: Respondents disadvantaged through a lack of information } \\
\hline \multirow{3}{*}{$\begin{array}{l}\text { Percentage } \\
\text { disadvantaged }\end{array}$} & \multicolumn{5}{|c|}{ Status } & \multicolumn{6}{|c|}{ Social class } & \\
\hline & Empl & $\begin{array}{l}\text { Seek } \\
\text { work }\end{array}$ & Retd & $\begin{array}{c}\text { Run } \\
\text { home }\end{array}$ & Studt & I & II & $\begin{array}{l}\text { III } \\
\text { (N) }\end{array}$ & $\begin{array}{l}\text { III } \\
\text { (M) }\end{array}$ & IV & $\mathbf{v}$ & $\begin{array}{c}\text { Entire } \\
\text { Sample }\end{array}$ \\
\hline & 31.9 & 23.1 & 18.9 & 26.1 & 30.8 & 42.9 & 33.3 & 23.6 & 11.8 & 27.1 & 17.6 & 26.1 \\
\hline
\end{tabular}

The next section of the survey sought to measure how well-informed the sample was about citizenship information matters and to examine levels of participation in the democratic process.

Respondents were firstly asked how well informed they felt they were about five different citizenship topics (see Tables 11a and 11b). The majority felt well or adequately informed about these subjects, although over a quarter of the sample in each case felt poorly informed about legal rights, welfare benefits and local politics. Respondents in the higher classes were better informed and more interested in national politics than the lower classes: for instance, of the Class I respondents, $53.1 \%$ were well informed and none was not interested, while of the Class IV respondents, just 6.3\% felt well informed and 39.6\% were uninterested. With regard to welfare benefits, a far smaller proportion of Class $\mathrm{V}$ respondents were uninterested $(11.8 \%)$ than in the other classes (all over 20\%). With equal rights, meanwhile, students 
were the most informed and interested group, while retired respondents were relatively poorly informed and least interested.

\begin{tabular}{|c|c|c|c|c|c|c|c|c|c|c|c|c|}
\hline \multicolumn{13}{|c|}{$\begin{array}{l}\text { Table 11a: Awareness of various citizenship topics } \\
\text { adequately informed (\%) }\end{array}$} \\
\hline \multirow[b]{2}{*}{ Topic } & \multicolumn{5}{|c|}{ Status } & \multicolumn{6}{|c|}{ Social class } & \multirow[b]{2}{*}{$\begin{array}{l}\text { Entire } \\
\text { Sample }\end{array}$} \\
\hline & Empl & $\begin{array}{l}\text { Seek } \\
\text { work }\end{array}$ & Retd & $\begin{array}{c}\text { Run } \\
\text { home }\end{array}$ & Studt & I & II & $\begin{array}{l}\text { III } \\
\text { (N) }\end{array}$ & $\begin{array}{l}\text { III } \\
\text { (M) }\end{array}$ & IV & $\mathbf{V}$ & \\
\hline National politics & 70.6 & 61.5 & 72.0 & 62.2 & 69.2 & 93.9 & 78.4 & 69.1 & 64.7 & 43.4 & 29.4 & 69.3 \\
\hline Local politics & 57.5 & 43.1 & 67.4 & 47.9 & 48.7 & 71.4 & 59.8 & 45.4 & 52.9 & 50.0 & 52.9 & 57.6 \\
\hline Legal rights & 60.6 & 56.9 & 59.3 & 55.5 & 64.1 & 67.3 & 67.6 & 60.0 & 47.1 & 45.8 & 58.8 & 59.7 \\
\hline Welfare benefits & 38.1 & 72.3 & 58.6 & 53.8 & 52.6 & 26.5 & 42.2 & 36.4 & 23.5 & 39.6 & 52.9 & 51.0 \\
\hline Equal rights & 70.9 & 67.7 & 59.6 & 64.7 & 75.6 & 75.5 & 80.4 & 74.5 & 52.9 & 66.7 & 41.2 & 66.4 \\
\hline
\end{tabular}

\begin{tabular}{|c|c|c|c|c|c|c|c|c|c|c|c|c|}
\hline \multirow[b]{2}{*}{ Topic } & \multicolumn{5}{|c|}{ Status } & \multicolumn{6}{|c|}{ Social class } & \multirow[b]{2}{*}{$\begin{array}{l}\text { Entire } \\
\text { Sample }\end{array}$} \\
\hline & Empl & $\begin{array}{c}\text { Seek } \\
\text { work }\end{array}$ & Retd & $\begin{array}{c}\text { Run } \\
\text { home } \\
\end{array}$ & Studt & $\begin{array}{l}I \\
\end{array}$ & II & $\begin{array}{l}\text { III } \\
\text { (N) }\end{array}$ & $\begin{array}{l}\text { III } \\
\text { (M) }\end{array}$ & IV & $\mathbf{V}$ & \\
\hline National politics & 29.1 & 38.5 & 27.7 & 37.8 & 29.5 & 6.1 & 21.6 & 30.9 & 35.3 & 56.3 & 70.6 & 30.4 \\
\hline Local politics & 42.5 & 56.9 & 32.2 & 51.3 & 51.3 & 28.6 & 40.2 & 54.5 & 47.1 & 50.0 & 47.1 & 42.2 \\
\hline Legal rights & 39.1 & 43.1 & 39.7 & 44.5 & 35.9 & 30.6 & 32.4 & 40.0 & 52.9 & 54.2 & 41.2 & 39.9 \\
\hline Welfare benefits & 61.6 & 27.7 & 40.7 & 46.2 & 47.4 & 71.4 & 57.8 & 63.6 & 76.5 & 60.4 & 47.1 & 48.5 \\
\hline Equal rights & 29.1 & 32.3 & 39.4 & 35.3 & 23.1 & 24.5 & 19.6 & 25.5 & 47.1 & 33.3 & 58.8 & 33.2 \\
\hline
\end{tabular}

Respondents were provided with a list of six types of group or association and asked if they were a member of any (see Table 12). There were low levels of participation in these groups overall, with the highest proportions being for membership of leisure (32.4\%) and charitable (25.2\%) groups. Only small minorities were members of professional or trade associations ( $16.6 \% ; 50.2 \%$ of those in employment), trade unions (13.6\%; $41 \%$ of those in employment), pressure groups $(6.9 \%)$ or political parties $(6.7 \%)$. Membership of pressure groups was greater amongst employed respondents (11.3\%) and amongst Classes I (24.5\%) and II (15.7\%). Membership of charitable groups was also significantly higher in Classes I (38.8\%) and II (37.3\%), but lower amongst those running a home (15.1\%) and jobseekers (12.3\%). Classes I and II also included greater proportions of members of professional/trade associations and leisure groups. So group membership was clearly affected by status and class and could potentially have a significant impact on access to information. 


\begin{tabular}{|c|c|c|c|c|c|c|c|c|c|c|c|c|}
\hline \multicolumn{13}{|c|}{ Table 12: Group membership (\%) } \\
\hline \multirow[b]{2}{*}{ Type of group } & \multicolumn{5}{|c|}{ Status } & \multicolumn{6}{|c|}{ Social class } & \\
\hline & Empl & $\begin{array}{l}\text { Seek } \\
\text { work }\end{array}$ & Retd & $\begin{array}{l}\text { Run } \\
\text { home }\end{array}$ & Studt & $\mathbf{I}$ & II & $\begin{array}{l}\text { III } \\
\text { (N) }\end{array}$ & $\begin{array}{l}\text { III } \\
\text { (M) }\end{array}$ & IV & $\mathbf{V}$ & $\begin{array}{c}\text { Entire } \\
\text { Sample }\end{array}$ \\
\hline Leisure & 35.0 & 23.1 & 35.2 & 20.2 & 38.5 & 57.1 & 38.2 & 34.5 & 23.5 & 22.9 & 5.9 & 32.4 \\
\hline Charitable & 29.1 & 12.3 & 30.3 & 15.1 & 16.7 & 38.8 & 37.3 & 18.2 & 17.6 & 25.0 & 5.9 & 25.2 \\
\hline Prof/trade assoc. & 33.4 & 4.6 & 8.1 & 2.5 & 12.8 & 71.4 & 48.0 & 14.5 & 29.4 & Nil & Nil & 16.6 \\
\hline Trade union & 29.1 & 3.1 & 5.2 & 4.2 & 6.4 & 38.8 & 31.4 & 18.2 & 29.4 & 35.4 & 17.6 & 13.6 \\
\hline Pressure group & 11.3 & 4.6 & 4.2 & 4.2 & 5.1 & 24.5 & 15.7 & 7.3 & Nil & 2.1 & Nil & 6.9 \\
\hline Political party & 7.2 & 4.6 & 8.1 & 3.4 & 5.1 & 8.2 & 7.8 & 5.5 & Nil & 6.3 & Nil & 6.7 \\
\hline
\end{tabular}

Respondents were asked how regularly they vote at elections (see Table 13). The numbers who said they always vote at national (77.2\%), local (65.8\%) and European (45.3\%) elections were higher than the most recent actual turnouts for these votes [22,23,24] particularly for local elections, suggesting that respondents tended to overestimate their participation in this respect. In all three types of elections, voting was most regular amongst retired respondents and lowest amongst the jobseekers and students. The survey also asked respondents whether, apart from voting, they actively participated in the democratic process. Just $10.2 \%$ participated in other forms of political activity such as canvassing and campaigning. Participation was particularly high amongst Class I respondents (20.4\%).

\begin{tabular}{|l|c|c|c|c|c|c|c|c|c|c|c|c|}
\hline Table 13: Respondents who always vote at elections (\%) \\
\hline \multirow{2}{*}{$\begin{array}{l}\text { Type of } \\
\text { election }\end{array}$} & \multicolumn{7}{|c|}{ Status } \\
\cline { 2 - 14 } & Empl & $\begin{array}{c}\text { Seek } \\
\text { work }\end{array}$ & Retd & $\begin{array}{c}\text { Run } \\
\text { home }\end{array}$ & $\begin{array}{c}\text { Studt } \\
*\end{array}$ & I & II & $\begin{array}{c}\text { III } \\
\text { (N) }\end{array}$ & $\begin{array}{c}\text { III } \\
\text { (M) }\end{array}$ & IV & V & $\begin{array}{c}\text { Entire } \\
\text { Sample }\end{array}$ \\
\hline National & 78.8 & 56.9 & 88.6 & 73.1 & 57.4 & 89.8 & 81.4 & 74.5 & 82.4 & 64.6 & 58.8 & $\mathbf{7 7 . 2}$ \\
\hline Local & 64.1 & 44.6 & 81.8 & 58.8 & 44.1 & 65.3 & 61.8 & 67.3 & 58.9 & 58.3 & 52.9 & $\mathbf{6 5 . 8}$ \\
\hline European & 45.6 & 26.2 & 57.7 & 37.0 & 29.4 & 53.1 & 53.9 & 38.2 & 35.3 & 31.3 & 23.5 & $\mathbf{4 5 . 3}$ \\
\hline
\end{tabular}

* Percentage is of those students who were eligible to vote

The survey also asked respondents for their opinion on the importance of freedom of information and if they felt that access to accurate and unbiased information was important for exercising their rights as citizens (see Table 14). The vast majority (91.7\% in both cases) felt that these issues were important, reinforcing the similar finding in the first survey. However, those respondents in unskilled occupations (Class V) appeared to place less importance on access to information (-27.0). Unlike the situation in Survey 1, there were no significant differences between the attitudes of students and those of the other groups. 


\begin{tabular}{|c|c|c|c|c|c|c|c|c|c|c|c|c|}
\hline \multicolumn{13}{|c|}{$\begin{array}{l}\text { Table 14: Freedom of information and access to accurate and unbiased information (\% who } \\
\text { believed them to be important) }\end{array}$} \\
\hline & \multicolumn{5}{|c|}{ Status } & \multicolumn{6}{|c|}{ Social class } & \multirow[b]{2}{*}{$\begin{array}{l}\text { Entir } \\
\text { Semple }\end{array}$} \\
\hline & Empl & $\begin{array}{l}\text { Seek } \\
\text { work }\end{array}$ & Retd & $\begin{array}{l}\text { Run } \\
\text { home }\end{array}$ & Studt & $\mathbf{I}$ & II & $\begin{array}{l}\text { III } \\
\text { (N) }\end{array}$ & $\begin{array}{l}\text { III } \\
\text { (M) }\end{array}$ & IV & $\mathbf{V}$ & \\
\hline $\begin{array}{l}\text { Freedom of } \\
\text { information }\end{array}$ & 94.7 & 89.2 & 89.3 & 89.9 & 94.9 & 95.9 & 95.1 & 92.7 & 94.1 & 91.7 & 94.1 & 91.7 \\
\hline $\begin{array}{l}\text { Access to } \\
\text { information }\end{array}$ & 93.4 & 83.1 & 91.2 & 90.8 & 92.3 & 100 & 96.1 & 94.5 & 94.1 & 85.4 & 64.7 & 91.7 \\
\hline
\end{tabular}

The next section of the survey paid particular attention to the use of Information and Communication Technologies (ICTs). In a closed question, respondents were asked about current levels of access to ICTs. Access to computers (39.3\%), the Internet (14.6\%) and satellite/cable television (26.4\%) in the home was limited, while $35.3 \%$ of those in employment had access to the Internet at work. Again, status and social class had a significant impact on the results: home computer ownership was highest amongst students (64.1\%) and the employed respondents (56.6\%), particularly those in Class I (81.6\%), and lowest amongst the retired (15.6\%). Perhaps surprisingly, satellite/cable TV ownership was highest amongst respondents running a home (42.9\%) and jobseekers (38.5\%).

The respondents were asked if they would use computers to take part in any of four different democratic activities, if computers were available for them to use either at home, at work or in public places (see Table 15). A slight majority in each case would be willing to use computers to vote, make their own feelings known or obtain government information, although there was a reluctance to use computers to participate in debates. In each case, students would be the most willing users while retired people would be the most reluctant status group. There was also a general trend for those in higher social classes to be more willing to use computers for these purposes.

\begin{tabular}{|c|c|c|c|c|c|c|c|c|c|c|c|c|}
\hline \multicolumn{13}{|c|}{ Table 15: Potential use of computers to participate in democratic activities (\%) } \\
\hline \multirow[b]{2}{*}{ Activity } & \multicolumn{5}{|c|}{ Status } & \multicolumn{6}{|c|}{ Social class } & \multirow[b]{2}{*}{$\begin{array}{l}\text { Entire } \\
\text { Sample }\end{array}$} \\
\hline & Empl & $\begin{array}{l}\text { Seek } \\
\text { work }\end{array}$ & Retd & $\begin{array}{l}\text { Run } \\
\text { home }\end{array}$ & Studt & I & II & $\begin{array}{l}\text { III } \\
\text { (N) }\end{array}$ & $\begin{array}{l}\text { III } \\
\text { (M) }\end{array}$ & IV & $\mathbf{V}$ & \\
\hline Vote in elections & 63.4 & 64.6 & 35.5 & 60.5 & 78.2 & 73.5 & 64.7 & 69.1 & 64.7 & 50.0 & 41.2 & 54.7 \\
\hline $\begin{array}{l}\text { Take part in } \\
\text { debates }\end{array}$ & 43.4 & 41.5 & \begin{tabular}{|l|}
18.9 \\
\end{tabular} & 31.1 & 61.5 & 40.8 & 52.0 & 41.8 & 35.3 & 29.2 & 29.4 & 35.0 \\
\hline $\begin{array}{l}\text { Provide feedback } \\
\text { to Government }\end{array}$ & 68.1 & 55.4 & \begin{tabular}{|l|}
30.9 \\
\end{tabular} & 56.3 & 74.4 & 85.7 & 67.6 & 67.3 & 58.8 & 47.9 & 58.8 & 53.5 \\
\hline $\begin{array}{l}\text { Obtain official } \\
\text { Govt. information }\end{array}$ & 76.6 & 69.2 & 32.6 & 63.9 & 82.1 & 91.8 & 82.4 & 76.4 & 64.7 & 58.3 & 47.1 & 59.8 \\
\hline
\end{tabular}


Respondents were then asked if they might have concerns over confidentiality if they were to use a computer to interact with government. Of those who would use a computer to vote, $47.7 \%$ were worried about confidentiality, while similar figures were found amongst those who would use computers to debate (47.5\%) and provide feedback to government (50.6\%). There were no significant differences in terms of status and class.

From a list of five methods, respondents were asked how they would prefer to make their own feelings known on a subject they felt particularly strongly about. The traditional method of writing to someone was preferred by the majority of respondents $(66.4 \%)$, with smaller proportions preferring to speak at a public meeting (5.8\%), debate by computer (5.5\%), phone in to a radio/TV debate $(4.7 \%)$ or appear in front of the cameras during a televised debate $(2.3 \%)$. Particular classes appeared to be more willing to use particular methods: a significantly higher proportion (17.6\%) of respondents with skilled manual occupations would speak at a public meeting; while $10.2 \%$ of those with professional occupations would speak on a televised debate. A substantial proportion (15\%) of the sample were not interested in making their feelings known, a trend particularly manifest amongst the retired respondents $(22.8 \%)$.

The survey then explored the public's use of libraries and other information sources. From a list of 11 organisations, individuals and locations, respondents were asked from which one they would prefer to obtain official government information (see Table 16). Public libraries were the most popular source, cited by $43.2 \%$ of respondents, reinforcing the finding of the first survey. While the public library was the top source of all status groups and social classes, jobseekers displayed a particular interest in using post offices (20\%) and council offices (13.8\%), while use of CABx would be highest amongst the retired (18.6\%). 


\begin{tabular}{|c|c|c|c|c|c|c|c|c|c|c|c|c|}
\hline \multicolumn{13}{|c|}{ Table 16: Preferred source of Government information (\%) } \\
\hline \multirow[b]{2}{*}{ Source } & \multicolumn{5}{|c|}{ Status } & \multicolumn{6}{|c|}{ Social class } & \multirow[b]{2}{*}{$\begin{array}{r}\text { Entire } \\
\text { Sample }\end{array}$} \\
\hline & Empl & $\begin{array}{c}\text { Seek } \\
\text { work }\end{array}$ & Retd & $\begin{array}{c}\begin{array}{c}\text { Run } \\
\text { home }\end{array} \\
\text {. }\end{array}$ & Studt & $\mathbf{I}$ & II & $\begin{array}{l}\text { III } \\
\text { (N) }\end{array}$ & $\begin{array}{l}\text { III } \\
\text { (M) }\end{array}$ & IV & $\mathbf{V}$ & \\
\hline Public libraries & 45.3 & 40.0 & 39.4 & 40.3 & 55.1 & 49.0 & 43.1 & 38.2 & 41.2 & 50.0 & 29.4 & 43.2 \\
\hline Post offices & 12.8 & 20.0 & 16.6 & 17.6 & 6.4 & 8.2 & 13.7 & 16.4 & 11.8 & 16.7 & 11.8 & 14.7 \\
\hline $\mathrm{CABx}$ & 7.2 & 7.7 & 18.6 & 13.4 & 7.7 & 6.1 & 4.9 & 7.3 & 17.6 & 10.4 & 5.9 & 12.0 \\
\hline Local MP & 3.4 & 7.7 & 7.5 & 9.2 & 1.3 & Nil & 3.9 & Nil & Nil & 4.2 & 17.6 & 5.8 \\
\hline Council offices & 5.0 & 13.8 & 3.6 & 7.6 & 3.8 & 6.1 & 2.9 & 5.5 & 5.9 & 8.3 & 11.8 & 5.5 \\
\hline $\begin{array}{l}\text { Govt. depts and } \\
\text { agencies }\end{array}$ & 5.3 & Nil & 3.9 & 2.5 & 5.1 & 6.1 & 8.8 & 3.6 & 5.9 & 2.1 & Nil & 4.0 \\
\hline Schools & 5.0 & Nil & 0.3 & 3.4 & 14.1 & Nil & 6.9 & 9.1 & Nil & 2.1 & 11.8 & 3.6 \\
\hline $\begin{array}{l}\text { Computers in } \\
\text { public places }\end{array}$ & 6.6 & 6.2 & 1.0 & Nil & 3.8 & 12.2 & 6.9 & 5.5 & Nil & 2.1 & 5.9 & 3.5 \\
\hline $\begin{array}{l}\text { Banks and } \\
\text { building socs. }\end{array}$ & 3.8 & 3.1 & 1.3 & Nil & Nil & 4.1 & 3.9 & 7.3 & 5.9 & Nil & Nil & 2.0 \\
\hline $\begin{array}{l}\text { Medical centres } \\
\text { and surgeries }\end{array}$ & 1.3 & Nil & 1.0 & 1.7 & Nil & Nil & 1.0 & 3.6 & Nil & Nil & 5.9 & 1.0 \\
\hline $\begin{array}{l}\text { Community/ } \\
\text { leisure centres }\end{array}$ & 0.6 & Nil & 0.3 & Nil & 1.3 & Nil & 2.0 & Nil & Nil & Nil & Nil & 0.4 \\
\hline
\end{tabular}

The respondents were also asked for what reasons they would prefer to obtain information from their chosen source. For most respondents it was the accessibility and the fact that they visited it regularly that made the library their preference. Libraries were also seen as reputable and having an appropriate atmosphere. Those that preferred MPs and government departments were motivated by getting their information directly from the primary source. CABx were also seen as particularly reputable and having very helpful staff.

Of the entire sample, $72.5 \%$ were members of a public library, higher than the recently quoted national figure of 58\% [25]. Membership was highest amongst students (88.5\%) and lowest amongst jobseekers (64.6\%) and those running a home (63.9\%). Membership was also higher amongst the higher classes, ranging from $47.1 \%$ of Class V to $79.4 \%$ of Class II (see Table 17).

\begin{tabular}{|c|c|c|c|c|c|c|c|c|c|c|c|c|}
\hline \multirow{3}{*}{$\begin{array}{l}\text { Public library } \\
\text { member }\end{array}$} & \multicolumn{5}{|c|}{ Status } & \multicolumn{6}{|c|}{ Social class } & \multirow{3}{*}{$\begin{array}{r}\begin{array}{r}\text { Entire } \\
\text { Sample }\end{array} \\
72.5\end{array}$} \\
\hline & Empl & $\begin{array}{l}\begin{array}{l}\text { Seek } \\
\text { work }\end{array} \\
\end{array}$ & \begin{tabular}{|l|} 
Retd \\
\end{tabular} & $\begin{array}{l}\text { Run } \\
\text { home } \\
\end{array}$ & Studt & I & II & $\begin{array}{l}\text { III } \\
\text { (N) }\end{array}$ & $\begin{array}{l}\text { III } \\
\text { (M) }\end{array}$ & IV & $\mathbf{V}$ & \\
\hline & $\begin{array}{l}72.8 \\
\end{array}$ & $\begin{array}{ll}64.6 \\
\end{array}$ & \begin{tabular}{|l|}
73.0 \\
\end{tabular} & 63.9 & 88.5 & 77.6 & 79.4 & 65.5 & 58.8 & 68.8 & 47.1 & \\
\hline
\end{tabular}

The sample was asked if public libraries were suitable places for obtaining information on five topics: their local council; welfare benefits, job opportunities and careers; housing; and consumer advice. The vast majority $(82 \%)$ believed that libraries were appropriate locations 
for council information, while smaller majorities in each case felt that libraries should provide information on the other four topics (see Table 18). There appeared to be some doubts over whether libraries should hold housing information, particularly among the lower classes: $52.9 \%$ of Class V and 52.1\% of Class IV believed libraries should not hold such information.

\begin{tabular}{|c|c|c|c|c|c|c|c|c|c|c|c|c|}
\hline \multicolumn{13}{|c|}{ Table 18: Suitability of public libraries for obtaining information on particular topics (\%) } \\
\hline \multirow{2}{*}{$\begin{array}{l}\text { Type of } \\
\text { information }\end{array}$} & \multicolumn{5}{|c|}{ Status } & \multicolumn{6}{|c|}{ Social class } & \multirow[b]{2}{*}{$\begin{array}{l}\text { Entire } \\
\text { Sample }\end{array}$} \\
\hline & Empl & $\begin{array}{l}\text { Seek } \\
\text { work }\end{array}$ & Retd & $\begin{array}{l}\text { Run } \\
\text { home }\end{array}$ & Studt & I & II & $\begin{array}{l}\text { III } \\
(\mathrm{N})\end{array}$ & $\begin{array}{l}\text { III } \\
\text { (M) }\end{array}$ & IV & $\mathbf{V}$ & \\
\hline Local council & 85.6 & 75.4 & 79.8 & 85.7 & 74.4 & 83.7 & 89.2 & 87.3 & 76.5 & 81.3 & 94.1 & 82.0 \\
\hline Welfare benefits & 67.8 & 63.1 & 64.8 & 65.5 & 56.4 & 67.3 & 73.5 & 67.3 & 47.1 & 62.5 & 58.8 & 65.1 \\
\hline Jobs/careers & 62.5 & 64.6 & 59.0 & 63.0 & 61.5 & 71.4 & 63.7 & 72.7 & 41.2 & 52.1 & 52.9 & 61.4 \\
\hline Housing & 54.4 & 49.2 & 55.0 & 52.9 & 48.7 & 63.3 & 58.8 & 54.5 & 41.2 & 39.6 & 41.2 & 53.5 \\
\hline Consumer & 70.3 & 61.5 & 66.8 & 65.5 & 67.9 & 75.5 & 75.5 & 76.4 & 47.1 & 56.3 & 64.7 & 67.8 \\
\hline
\end{tabular}

Those respondents who believed libraries were inappropriate places for the five types of information were asked to suggest more suitable locations. Local council offices were seen as appropriate locations for council information; it was felt that benefits information should be held by CABx, DSS offices and council social services departments; job centres were regarded as appropriate sources of job and career information; council housing departments were deemed more appropriate for housing information; while $\mathrm{CABx}$ and consumer protection or trading standards offices were believed to be suitable sources of consumer advice. Status and social class were not significant factors in the response to this question.

The survey then investigated the respondents' awareness of the types of information held by public libraries. They were asked if they were aware that most libraries hold government publications and information on health care, educational opportunities, legal rights and the EU (see Table 19). Overall, 672 respondents (74.8\%) were unaware of at least one of the information types held by libraries, providing evidence of a real need for libraries to promote more effectively their collections and expertise in such areas. Awareness of government publications in libraries was considerably higher amongst the professional and managerial classes, while awareness of health care resources was significantly lower amongst those with skilled manual occupations. 


\begin{tabular}{|l|c|c|c|c|c|c|c|c|c|c|c|c|}
\hline \multicolumn{10}{|c|}{ Table 19: Awareness of types of information held by most public libraries (\%) } \\
\hline $\begin{array}{l}\text { Type of } \\
\text { information }\end{array}$ & Empl & $\begin{array}{l}\text { Seek } \\
\text { work }\end{array}$ & Retd & $\begin{array}{l}\text { Run } \\
\text { home }\end{array}$ & Studt & I & II & $\begin{array}{l}\text { III } \\
\text { (N) }\end{array}$ & $\begin{array}{c}\text { III } \\
\text { (M) }\end{array}$ & IV & V & $\begin{array}{c}\text { Entire } \\
\text { Sample }\end{array}$ \\
\hline $\begin{array}{l}\text { Official govt. } \\
\text { publications }\end{array}$ & 56.3 & 41.5 & 56.0 & 46.2 & 51.3 & 79.6 & 70.6 & 32.7 & 41.2 & 29.2 & 29.4 & $\mathbf{5 3 . 5}$ \\
\hline Health care & 56.3 & 49.2 & 50.2 & 52.9 & 59.0 & 69.4 & 58.8 & 52.7 & 17.6 & 56.3 & 52.9 & $\mathbf{5 3 . 6}$ \\
\hline $\begin{array}{l}\text { Educational } \\
\text { opportunities }\end{array}$ & 73.4 & 73.8 & 60.6 & 72.3 & 74.4 & 87.8 & 76.5 & 69.1 & 58.8 & 68.8 & 58.8 & $\mathbf{6 9 . 0}$ \\
\hline Legal rights & 57.5 & 55.4 & 48.9 & 48.7 & 61.5 & 69.4 & 57.8 & 60.0 & 41.2 & 41.7 & 47.1 & $\mathbf{5 3 . 7}$ \\
\hline European Union & 36.3 & 41.5 & 37.1 & 30.3 & 41.0 & 44.9 & 37.3 & 32.7 & 23.5 & 20.8 & 35.3 & $\mathbf{3 6 . 9}$ \\
\hline
\end{tabular}

\section{Conclusions}

The results of this project, although it did not specifically set out to do so, demonstrate that social class and status have a significant impact on many aspects of information need and patterns of information seeking behaviour. Many of these are as one would anticipate but there are several that suggest research questions that would merit further exploration.

Statistically significant variations were found that illuminate our understanding of the behaviour of the particular sub-groups of the population explored in the two surveys and the conclusions that follow focus upon the distinguishing characteristics that emerge from findings rather than upon the broad results that apply equally to all groups.

\section{Social Class I (Professional) and II (Managerial and Technical)}

This group demonstrated a significantly greater need for information on national politics, local government, the EU, law, technology and the environment and were more likely to predict a future need for European and leisure information. They tended to require information for work related, business and recreational reasons to a greater extent than other classes.

Group I and II respondents were more likely to approach public libraries, academic libraries and professional/trade associations and demonstrated a much greater tendency to prefer to use a computer to access information: proposed use of public access computers was highest amongst Class II respondents. Groups I and II were also more likely to use newspapers as a major information source for a range of current issues and tended to feel better informed on 
these issues. They were more aware that public libraries held government information. The group was less likely to have encountered a need for welfare benefits information but had a significantly greater tendency to be aware of an instance when a lack of information had resulted in personal disadvantage.

They were more likely to feel well informed about and interested in national politics and were more commonly members of pressure and charitable groups and of professional/trade associations and leisure groups. Participation in other forms of democratic activity, such as campaigning was also highest amongst Group I and II respondents. They were more likely to have a computer at home and were much more willing to use a computer to engage in democratic activities.

\section{Social Class III (Skilled non-manual and skilled manual), IV (Partly skilled) and V (Unskilled)}

Respondents from social classes III, IV and V demonstrated a greater need for educational information and were more likely to approach CABx for information. They showed a significantly lesser tendency to be willing to use a computer to access information, particularly amongst unskilled respondents: proposed future use of public access computers was lowest amongst Class IV respondents. Use of television as a major information source for a range of current issues was greater amongst these groups. Respondents tended to feel well informed about issues such as BSE.

These groups were more likely to have encountered a welfare benefits problems and would tend to a greater extent to approach DSS offices, CABx, council departments and family and friends for information as a result. However, these groups were less aware of instances where lack of access to information had resulted in disadvantage. They were less well informed about and interested in national politics and placed less emphasis on the importance of access to information in exercising their rights as citizens.

Respondents from groups III, IV and V were less willing to use computers to participate in democratic activities and tended not to be aware of some of the resources available in public libraries. 


\section{Employed respondents}

Employed respondents demonstrated few distinguishing characteristics. They demonstrated a significantly greater tendency to require information on law, employment and the environment and had a greater need for information for work related and business reasons. They were more likely to be members of trade/professional associations, trade unions and pressure groups and were, consequently, more likely to approach such groups for information. This group more frequently had a computer at home than did respondents in most of the other respondent groups.

\section{Job seekers}

Respondents who were seeking employment tended to need information about employment and welfare benefits but had a lesser requirement for leisure information. They had a greater tendency to predict a future increased need for housing, taxation, business and citizens' rights information and to feel that they would in the future, when employment was presumably secured, require information to a greater extent for work related, business and financial reasons. There was an expected emphasis on information for job seeking reasons and a more surprising lack of need for information for recreational reasons. This group demonstrated a greater tendency to be interested in employment issues and employment problems were most frequently cited by job seekers who tended to approach job centres and newspapers for information.

While $\mathrm{CABx}$ were a particularly important resource for this group, predicted future use of public libraries was very high although respondents were less frequently members of a public library at present. Job seekers were also more likely to approach post offices and council departments for information.

Job seekers tended not to be members of charitable groups and were less likely to vote. However, they were more likely than most respondents to have satellite or cable television installed at home. 


\section{Retired respondents}

Retired respondents demonstrated the greatest need for leisure information and a significantly lesser need for educational, employment, housing, family, business, legal, equal rights and technological information than did respondents in other groups. Equally they were less likely to require information for educational, work related, job seeking, business and legal reasons. They were less likely to approach all of the information sources dealt with in the survey apart from $\mathrm{CABx}$ which were cited more frequently by this group than by others. Retired respondents tended not to prefer to access information by face to face communication, by using a computer and by watching television and proposed use of public access computers was lower than for other groups.

They demonstrated the highest levels of interest in health issues and were more likely to make their feelings known about a current issue by approaching their local councillor. They tended not to be aware of instances where lack of access to information had resulted in personal disadvantage nor to report a need for information that might help in solving everyday problems.

Voting was most frequent amongst the retired, while home computer access was least common for this group. However, they were also least likely to use computers in order to participate in democratic activities and tended not to want to make their feelings known on current issues.

\section{Respondents running a home}

Respondents who were presently running a home were more likely to feel that $\mathrm{CABx}$ were a useful information source. They demonstrated a greater need for welfare benefits and family/personal information and a lesser requirement for information about the EU, business, Health \& Safety and equal rights. Family and health were the most frequently cited reasons for requiring information. They demonstrated a greater interest in education and health related current issues.

Those running a home were less likely to approach the majority of sources of information, but were more likely to approach professional people. They demonstrated a greater tendency 
to feel that a government information programme was desirable in dealing with issues such as BSE. Respondents in this group tended not to be members of charitable groups, but were more likely to have satellite or cable television in the home. They were also less likely to be members of public libraries.

\section{Students}

Students tended to demonstrate a greater need for educational, immigration and environmental information and a greater predicted future need for the majority of subjects. They were less interested in taxation, finance and legal matters. This group placed the greatest emphasis on information required for educational, political and religious reasons but showed less requirement for information for family, health, financial and legal reasons. They were also more likely to be able to cite an example of problems where information had been required to find a solution and were more aware of disadvantage as a result of an inability to access information. They were more interested in educational current issues than respondents from other groups. Students were also most likely to feel well informed about and interested in equal rights.

This was the group most likely to approach academic libraries, family/friends, advice centres, public libraries and post offices in seeking information, suggesting that they were more aware of the value of the range of resources available. They demonstrated a greater preference for face to face communications, using a computer and watching television than did other groups and were more likely to be members of a public library. Students tended to be more critical of the level of communication of information from councils about local government cutbacks. However, students were also less likely to vote than were respondents in other groups.

Home computer access was higher amongst students and they were the group most likely to use computers to engage in democratic activities. Proposed use of public access computers was also highest amongst students.

However, conversely, students tended to be less certain of the importance of access to information in exercising their rights as citizens than other groups, despite being more active users of many information sources and showing greater awareness of situations where lack of access had resulted in disadvantage. 
While the present project reveals that social class and status have an impact upon information need and information seeking behaviour, the pattern that emerges is not a simple one. It is clear that certain groups, such as those running a home and jobseekers, are not exploiting public library information resources as effectively as they might, while those in higher social classes and students are more aware of the potential of the public library. Equally, certain groups are less willing (or able) to take advantage of information and communications technologies to access information and participate in democratic activities. Interestingly, it is often those groups, predominantly the higher social classes and students, most willing to use a range of information sources that are most conscious of disadvantage resulting from a lack of information. These results demonstrate that there is a real danger of exclusion for certain groups of the population of the United Kingdom and that information policy must reflect an awareness of the most appropriate patterns of information dissemination in order to overcome barriers to access for each of these.

\section{References}

[1] Cabinet Office Social Exclusion Unit, Home page. Available at: http://www.cabinetoffice.gov.uk/seu/ (Visited December 1999).

[2] R. Marcella and G. Baxter, Citizenship information (British Library Research and Innovation Report no. 173) (British Library, London, 1999).

[3] D.J. Muddiman, Public libraries and social exclusion (BLRIC funded research project at Leeds Metropolitan University, October 1998 - March 2000).

[4] L. Tomos, COOL - Creating Opportunities for Others via Libraries (BLRIC funded research project at the University of Wales Aberystwyth, November 1998 - January 2000).

[5] C. Moore and H. Baigent, The EARL Consortium and social inclusion, Assignation 16(3) (1999) 30-33.

[6] F. Matarasso, Beyond book issues: the social potential of library projects (British Library Research and Innovation Report no. 87) (British Library, London, 1998).

[7] L. McKrell, A. Green and K. Harris, Libraries and community development: a report on the national survey of public library authorities (British Library Research and Innovation Report no. 86) (British Library, London, 1997).

[8] E. Kerslake and M. Kinnell, Reviewing the literature on public libraries and social inclusion, Libri 48(1) (1998) 1-12. 
[9] K. Harris, Open to interpretation: community perceptions of the social benefits of public libraries (British Library Research and Innovation Report no. 88) (British Library, London, 1998)

[10] R. Linley and B. Usherwood, New measures for the new library: a social audit of public libraries (British Library Research and Innovation Report no. 89) (British Library, London, 1998).

[11] B. Usherwood, Will the real CDG stand up please?, Impact, the Journal of the Career Development Group, 1(8) (1998) 124-127.

[12] National Working Party on Social Inclusion, The Net result: social inclusion in the Information Society (IBM, London, 1997).

[13] J. Pateman, A question of breeding, The Library Association Record 98(7) (1996) 362363.

[14] J. Pateman, Planning to tackle poverty, The Library Association Record 100(9) (1998) 472.

[15] J. Pateman, Public libraries and social class, Public Library Journal 13(5) (1998) 78-80.

[16] R. Marcella and G. Baxter, The information needs and the information seeking behaviour of a national sample of the population in the United Kingdom, with special reference to needs related to citizenship, Journal of Documentation 55(2) (1999) 159183.

[17] R. Marcella and G. Baxter, Information need, information seeking behaviour and participation, with special reference to needs related to citizenship: results of a national survey, Journal of Documentation 56(2) (2000) 136-160.

[18] Office of Population Censuses and Surveys, 1991 Census Small Area Statistics. Available through the University of Manchester's Manchester Information Datasets and Associated Services (MIDAS) at: http://cs6400.mcc.ac.uk/ (Visited March 1998).

[19] Office for National Statistics, Regional trends, 1997 edition (The Stationery Office, London, 1997).

[20] Office of Population Censuses and Surveys, Standard Occupational Classification (HMSO, London, 1990 vols 1 \& 2, 1991 vol 3).

[21] Central Information Technology Unit, government.direct: a prospectus for the electronic delivery of government services. Available at:

http://www.open.gov.uk/citu/gdirect/ (Visited March 1997).

[22] T. Austin (ed), The Times guide to the House of Commons, May 1997 (Times Books, London, 1998). 
[23] C. Rallings, M. Temple and M. Thrasher, Participation in local elections. In: L. Pratchett and D. Wilson (eds), Local democracy and local government.(Macmillan Press, Basingstoke, 1996).

[24] R. Morgan (ed), The Times guide to the European Parliament, June 1994 (Times Books, London,1994).

[25] Library and Information Commission, New library: the people's network (LIC, London, 1997). 